\title{
Al-'Aynī and His Fellow Historians: Questioning the Discursive Position of a Historian in the Academic Field in the Cairo Sultanate
}

\author{
Clément Onimus
}

The Near Eastern 15th century experienced a densification in history writing that led to a multiplication of historiographical works and an intensification of the interactions between historians. These interactions sometimes became a motivation to orient a passage of a text or even to be the topic of the text. In other words, the subjects who used to write history sometimes became the objects of history, either in their lifetimes or after their deaths. Such a literary situation invites us to propose a reflection on the social position of historians in the academic field. This reflection pays tribute to the historians who first introduced the linguistic turn, inaugurated by Hayden White, ${ }^{1}$ into Mamluk studies, like Ulrich Haarmann ${ }^{2}$ and Donald Little, ${ }^{3}$ whose work is still the base for all new reflections on this topic. Recently, this epistemological theme has been renewed by the works of Konrad Hirschler, ${ }^{4}$ Stephan Conermann, ${ }^{5}$ and Jo Van Steenbergen, ${ }^{6}$ who deepened the analysis on the literary construction of history and the role of the author. The questions asked by the linguistic turn meet here the work of Pierre Bourdieu ${ }^{7}$ and his definition of the social field as it has been introduced into Islamic studies by Michael Chamberlain ${ }^{8}$ and his research on the 'ulamä' of Damascus. At the same time, an intense reflection on Egyptian and Syrian historians is at work, led by several modern scholars, such as Frédéric Bauden ${ }^{9}$ on al-Maqrīz̄ì, René Guérin du Grandlaunay ${ }^{10}$ on al-

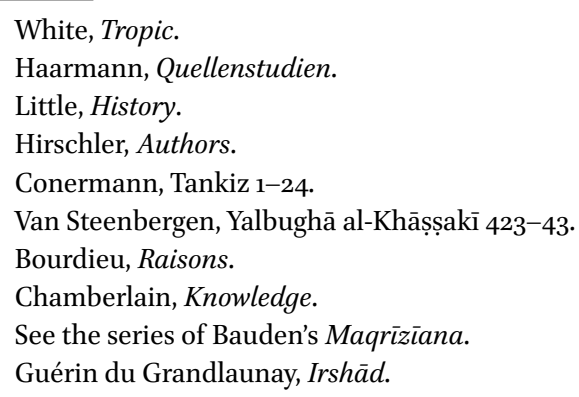


Sakhāwī, and Marlis J. Saleh on al-Suyūțī. ${ }^{11}$ Al-'Aynī has also been the topic of a few articles by Nobutaka Nakamachi ${ }^{12}$ and Anne Broadbridge, ${ }^{13}$ and he is one of the main characters in Joel Blecher's book on hadith commentary, which introduces Foucault's analysis into the field. ${ }^{14}$

At this crossroads between the linguistic turn, Bourdieu's concepts, and medieval Middle Eastern studies, we meet this Near Eastern 15th century and its group of interacting historians. As these historians mention each other as figures in the narration of the history of the sultanate, their social interactions were expressed in the framework of historiographical intertextuality, so that each one became a literary character under the pen of his colleagues as well as under his own pen. My point in this article will thus be to understand what discursive procedures were implemented in the polyphonic and dynamic elaboration of an author as a persona. Between social interaction and literary intertextuality, I shall argue that history writing is an act of social communication where the representation of the historian is a major stake.

Among these historians, Badr al-Dīn Mahmūd al-'Aynī is known to be a prominent scholar and one of the highest officials of the Cairo Sultanate during the first half of this century. An analysis of the discourse about al-Ayni in the historiographical writing in relation to a description of his own discourse about his peers should contribute to defining not only his social position but also the literary persona that created these interacting texts. Through the case study of this exceptionally controversial scholar, I shall study four aspects of this literarization of an author: the definition of the social status of the author, the matter of the critical discourse, the social and literary evaluation standards, and finally, the dynamic process of literarization.

Through various discursive procedures, the historians integrate or expel an author from among the academic elite. It appears that al-'Aynì did experience such a literary social expulsion under the pen of his fellow historians.

\footnotetext{
11 Saleh, Suyūṭī 73-89.

12 Nakamachi, al-'Aynīs chronicles 140-71.

13 Broadbridge, Academic $85^{-107}$. Anne Broadbridge gives a lot of detailed data related to al-'Aynī, al-Maqrīzī, Ibn Ḥajar, al-'Asqalānī, and their rivalry.

14 Blecher, Said the Prophet.
} 


\subsection{The Biographies and Their Absence}

One of the main historiographical genres was the biographical dictionary. The books of taräjim (i.e., biographies) present a series of short biographical notes about a number of people the author considers worthy of being remembered. This genre defines the milieu of the $a^{c} y \bar{a} n$, the notables. Thus, this genre creates the discursive reality of this social group and, at the same time, gives a historiographical existence and a literary unity of the life of each one of the individuals who is included in this milieu. In short, reading the life of al-'Aynī in the contemporary biographical dictionaries asks the question: What kind of notable was this individual considered to be? What kind of a'yān was al-'Aynī? Symmetrically, the absence of a biography of our author in a biographical dictionary must be questioned by the modern historian and come as a clue that the author considers its object as unworthy to be considered as a member of the elite.

Some of the contemporaries of al-'Aynī, such as Ibn al-Furāt and Ibn Khaldūn, did not write a word about him because they belonged to the previous generation who died before he became an important notable in Egypt. We cannot find a word about al-'Aynī in Ibn Duqmāq's work either, because his chronicle ends before al-'Ayni's rise. Nevertheless, some pieces of information about him can be found either in the biographies or the chronicles of two historians who belonged to the same generation and knew him personally: al-Maqrīzì in the Durar al-'uqū ${ }^{15}$ and Ibn Ḥajar al-'Asqālānī in the Raf' al-iṣr. ${ }^{16}$

\section{2}

\section{The Disappearing Intrigant}

There is no doubt that al-Maqrīzī wrote the very first biography of al-Aynī certainly before $829 / 1426$, as he was appointed to his office of Hanafĩ great judge during this year and it is not mentioned. Actually, the narrative of al-'Aynī's career stops in 801/1399 when he took the place of al-Maqrīzì at the office of muhtasib in Cairo. Nevertheless, al-Maqrīzī gives a list of al-Aynīs works (15 books are quoted), including his chronicle, which, he says, is composed of 20 volumes. This piece of information shows that this list had been written later, at the end of his life in 845/1442, as the twentieth volume of al-Ayni's Iqd al-jumān ends in 850/1446. It is then clear that al-Maqrīzī has supplemented this short biography although he was reluctant to add any word concerning al-'Aynì's later career and professional success.

\footnotetext{
15 Al-Maqrīzī, Durar al-'uqūd iii, 467-8.

16 Ibn Ḥajar, Raf' 432.
} 
Al-Maqrīzī narrates only the beginning of al-'Aynī's career in a few words that were probably inspired by al-'Ayni's autodocumentary mentions ${ }^{17}$ in the volume of his chronicle that deals with Sultan Barqūq's reign, ${ }^{18}$ which was obviously written before the end of his reign. ${ }^{19}$ Al-Maqrīzì's longstanding quarrel with al-Ayni has then determined both the way he wrote the biography and the fact that he chose not to copy it in the Muqaffa. ${ }^{20}$ The beginning of the quarrel in 8o1/1399 was a sufficient reason to expel any further information, just like if, in al-Maqrīzī's eyes, al-'Aynī no longer was a member of the $a$ 'yān after he took the hisba from him. Nevertheless, this quarrel is also a historiographical invention; not that it did not happen, but it was actually a very classical event in the competition for an office. Not just al-Maqrīzī and al-'Aynī but also five or six other people from the judge's milieu used to alternate as holder of the offices of muhtasib and nāzir al-ahbās (inspector of the pious foundations) according to the evolution of the balance of power between the amirs' factions. ${ }^{21}$ Be that as it may, it is worthy to note that al-Maqrīzì considered that this event meant the end of al-'Ayni belonging to the $a^{\prime} y \bar{a} n$ milieu, even though it was one of the causes of his own retirement from the competition for offices in order to concentrate on history writing. It is not impossible that al-Maqrīzī wrote this page while al-'Aynī's career did actually suffer a gap (between 804 and 818/1402 and 1415), but the coincidence with his own failure in the public career is meaningful; nothing could be said about his rival after his own retirement. ${ }^{22}$

\subsection{The Question of the Biographical Genre}

Ibn Hajar did not include al-'Aynī in the al-Durar al-kāmina or in its Dhayl, but we find a biography in the Raf' al-ișr 'an quḍāt Mișr, a biographical dictionary of the judges of Egypt that he wrote, as the title explains, in order to defend the reputation of these judges. ${ }^{23}$ This page was written when al-'Aynī was still alive,

17 I refer here to this notion as used in Hirschler, Authors.

18 Al-'Aynī, Iqd, ed. Shukrī, 192-3.

19 In the beginning of the volume, al-'Aynī prays for the length of Barqūq's reign. Al-'Aynī, Iqd, ed. Shukrī, 120.

20 Al-Maqrīzī did not write a biography of al-'Aynī in the Muqaffā, although most of the main historians, judges, and scholars of his time are mentioned in this book.

21 Among these people from the judges' milieu were: Jamāl al-Dīn Muhammad b. 'Umar al-Ṭandabī, Shams al-Dīn Muhammad al-Bakhānisī, Nāṣir al-Dīn Muḥammad al-Ṭunāḥ̄, Shams al-Dīn Muhammad b. al-Bannā.

22 On the academic rivalry between al-'Aynī and his colleagues, see Broadbridge, Academic 85-107. For a detailed record of al-'Aynī's career, see the introductions of Hajeri, $A$ critical edition, and Ma'tūq, Badr al-Dìn al-'Aynī.

23 Tillier, Vie 6. 
as he died after Ibn Hajar (773-852/1371-1449), and more specifically after his dismissal from the judiciary in $842 / 1438$, which is mentioned in the Raf' al-ișr. There is a second biography of al-'Aynī written by Ibn Hajar, hidden in the obituary of his father in the Inba al-ghumr. ${ }^{24}$ It is explicitly reliant on al-'Ayni's own words in the 'Iqd al-jumān and looks like al-Maqrīzi's biography, as it ends with his appointment to the hisba in 801/1399. We can, therefore, assume that it was written before al-'Aynī's appointment to higher offices during Sultan Barsbāy's reign.

Generally speaking, these three biographies do not look like classical 'ulam $\bar{a}^{\text {' }}$ biographies. The taräjim and obituaries of 'ulam $\bar{a}$ ' are standardized with the same pattern: first the family, then the student's journey (rihlat al-talab) and the teachers, then the positions and teachings, and finally, the works. Here the biographies only emphasize the positions and the interactions with high dignitaries and officials. The form is the main criticism: The fact that the text does not look like a classical 'ulamä biography shows that, at that time, al-Aynī was considered neither by al-Maqrīzì nor by Ibn Ḥajar as a true scholar, that is, a man who would be worthy of interacting with them. ${ }^{25}$ On the whole, both contemporary historians demonstrate themselves as reluctant to present comprehensive details about the formation, the teachers, the works, and the career of one of the main officials of the realm, although they both revised their text later. This reluctance to admit al-'Ayni into the academic elite echoes Foucault's notion of the "rarefaction of the speaking subjects," as in these biographies, he appears to be considered illegitimate and unable to take part in the academic discourse society. ${ }^{26}$

\section{The Relativity of the Social Position of the Author}

The chronicles give more details on al-Aynī than the biographies. The first mention of him comes from the annals of the same authors-al-Maqrīzī's Sulük and Ibn Hajar's Inbä' al-ghumr. In both chronicles, al-'Aynï's first appearance is his appointment as a muhtasib in 801/1399, ${ }^{27}$ which ends the Durar al-'uqūd's biography. The formation of the author-his studies, teachers, and licenses-is

\footnotetext{
24 Ibn Ḥajar, Inbä’ ii, 107-8.

25 It would have been interesting to find obituaries of al-'Aynī by al-Maqrīzī and Ibn Ḥajar, but both of them died before our subject. By "classical 'ulamä’ biography," I mean the tarjama as it is described by D. Eickelman in the EI. See Eickelman, Tardjama 242-3.

26 Foucault, L'ordre 38-49.

27 Al-Maqrīzì, Sulūk iii, 970; Ibn Ḥajar, Inbā’ iv, 33-4.
} 
not mentioned in the chronicles, as it is a minor aspect of the biographies. ${ }^{28}$ Indeed, his formation might have been of a lower level than that of his rivals. Blecher demonstrates that al-Aynī followed Ibn Hajar by presenting his intellectual genealogy at the beginning of his commentary of al-Bukhārī's Șahīh, but without the ability to challenge his rivals' four-branch, tremendous intellectual genealogy. ${ }^{29}$ Implicitly, the negligence of the formation means that, in the eyes of his fellow historians, al-Ayni’s life and career, as presented by Joel Blecher through the thought of Alasdair MacIntyre, did not fit the standards of excellence that are expected of an elite scholar. ${ }^{30}$ In other words, he owes his brilliant career to unacademic skills.

\subsection{A Criticism of the Social Ascension}

The chronicles emphasize an aspect that is mentioned in every biography of our author: his close relationships with the military elite. In the biography of the Durar al-'uqūd, al-Maqrīzì shows an unusual insistence on the intercessions he benefited from and that helped him to obtain different offices. The first one came from a scholar-Shaykh al-Sayrāmī — who had just been appointed to the management of the newly built madrasa al-Zāhiriyya. Al-'Aynī met him as they were both making a pilgrimage in Jerusalem and followed him to Cairo, where al-Sayrāmī appointed him as a Sufi in the madrasa. He then evokes an event that all the other historians mention without any details: In 79o/1388, al'Aynī was submitted to the humiliation of being expelled from the madrasa by its administrator, Amīr Jarkas al-Khalīlī. ${ }^{31}$ A few lines below, he insists on al'Aynì's intimacy with the Turks (i.e., the military elite), and particularly Amīr Jakam min 'Iwaḍ, who became his patron. Al-Maqrīzì tells that al-Aynī was appointed muhtasib instead of him thanks to Amīr Jakam, which means that he was not appointed for his skills, honesty, and competency but thanks to his intrigues.

In both their chronicles, al-Maqrīzī and Ibn Hajar have a common way of dealing with al-Aynī's commitment with the military elite and repeat the same anecdotes. They both explain that he was a client of Amīr Jakam (d. 8o9/1407). Ibn Hajar also says that Jakam interceded in his favor in 801/1399, ${ }^{32}$ and al-

28 Only one of his Aleppine teachers is mentioned in the Durar al-'uqūd and Ibn Ḥajar, in the $R a f^{\prime}$, names only the ones who had been his own teachers as well.

29 Blecher, Said the Prophet 106-8.

30 Ibid. 26.

31 Al-Maqrīzī, Durar al-'uqūd iii, 467-8; Ibn Ḥajar, Raf' 432 .

32 He adds that he read this piece of information in al-'Ayni’s chronicle. Ibn Hajar, Inbä' iv, $33^{-4}$. 
Maqrīzī relates that Jakam made him a muhtasib in 803/1400.33 Al-Maqrīzī and Ibn Hajar do not speak much about his relationships with Sultans Shaykh and Tatatar, but they mention the intimacy between Sultan Barsbāy and al-'Aynī, to whom he used to read his own chronicle, ${ }^{34}$ eventually in order to condemn this friendship, which led Barsbāy to some injustice ${ }^{35}$ or allowed al-'Aynī to expel a rival, al-Tifihnī, from the judiciary by plotting against him with the sultan. ${ }^{36}$ The special relationship that al-'Aynì had with the military elite, thanks to his fluency in Turkish, is linked to negative connotations.

The insistence on his intense interactions with the military elite is then a common feature of the way al-'Ayni is depicted by his colleagues, and a way to denigrate his successful career. It is an implicit criticism of his skills as a member of the judicial and academic milieu.

\subsection{The Question of the Qualifications}

Indeed, both al-Maqrīzī and Ibn Ḥajar question al-'Aynī's qualifications, either judicial or authorial.

\subsubsection{Questioning the Judicial Qualifications}

They both criticize al-Aynīs policy but according to their different personal agendas. Al-Maqrīzī spent a lot of ink questioning his exercise of the hisba, a position for which he used to compete with al-'Aynī, whereas Ibn Hajar constantly questions his exercise of judicial authority. ${ }^{37}$

Al-Maqrīzì's narrative of the scarcity of food in $818-9 / 1415^{-638}$ is an obvious summary of al-'Ayni’'s own narrative in the Iqd al-jumān. ${ }^{39}$ At that time, al-Ayni was the muhtasib of Cairo and thus responsible for the food supply of the capital city. But their texts present substantial differences. Al-'Aynī explains in detail the difficulties that his predecessors encountered at the hisba during the first months of the scarcity. He quotes at length his dialogue with Sultan alMu'ayyad Shaykh, who asked him to administer this office, and says that he first refused because the people used to blame the muhtasib for the drought. After

\footnotetext{
33 But he does not present such a commentary about his appointment in 8o1/1399. AlMaqrīzī, Sulūk iii, 1038.

34 Ibn Ḥajar, Raf ${ }^{`} 43^{2}$.

35 Al-Maqrī̄ī, Sulūk iv, 698.

36 Ibn Hajar, Inbä’ viii, 95-6.

37 Furthermore, both Ibn Hajar and al-Maqrīzī mention that al-'Aynī's exercise of the inspection of the waqfs (nazaral-ahbās) has been officially questioned and his accounts checked in 840/1436. Al-Maqrīzī, Sulūk iii, 10o2; Ibn Ḥajar, Inbä’ viii, 417.

38 Al-Maqrīzī, Sulūk iii, 343-4.

39 Al-'Aynī, Iqd, ed. al-Qarmūṭ i, 241-4.
} 
he agreed to wear the investiture robe, he went to the shore of Būlāq, where a lot of grain had arrived on boats, with Amir Īnāl al-Az'ar, who had been appointed as an auxiliary to him. The population rejoiced because bread was back in the bakeries, although it was still expensive.

In al-Maqrīzì's version, the appointment of al-'Aynì is directly linked to the absence of bread. Moreover, al-Aynī and İnāl's arrival to the shore of Būlāq is presented as a catastrophe. Fearing looting of the boats, the amir, who was under the command of the muhtasib, ordered his soldiers to charge against a dense but innocent mob. Some people were hurt; others executed. And despite the grain supply, it was sold at double its former price. In other words, al-Maqrīzì criticizes severely the way al-'Aynī performed the hisba through violence and injustice.

The second scarcity of food happened when al-'Aynī was in charge of the hisba in 828/1425. Although al-Aynī does not say a word about this event, alMaqrīzì deals with it at length. According to him, the population of Cairo assembled around his house to demonstrate and protest against his administration of this office, as they considered him responsible for this hard situation. He had to flee to the citadel because he feared they would throw stones at him and complained to Sultan al-Ashraf Barsbāy, who repressed the starving mob severely and arbitrarily. Al-Maqrīzī concludes by saying that people used to hate al-Aynī because of these events and adds that the prices continued to increase. Later, he explicitly accuses al-'Aynī of being the cause of the scarcity, because he did not coerce the sellers.

Whereas al-Maqrīzī presents al-'Aynī as an incompetent and violent muhtasib, Ibn Hajar is not that severe about his exercise of the hisba. On the contrary, he explains that al-Aynī had the courage to order the amirs to sell the grain of their granaries in $819 / 1416.40$

But Ibn Ḥajar constantly criticizes al-Aynīs exercise of judicial authority before and after his appointment as Ḥanafì great judge on Rabīi iI 22, $829 /$ March 3, 1426. A series of disagreements related to several judicial sentences are mentioned by the Shāfii great judge following a judgment of atheism against a Shāfíi scholar in Ramaḍān 828/July $1425 .{ }^{41}$ In 831/1428, another disagreement appeared about the legality of the destruction of a synagogue ordered by a Ḥanbalī judge and questioned by al-'Aynī. ${ }^{42}$ In 835/1432, Ibn Ḥajar

40 Ibn Hajar, Inb $\bar{a}^{\text {}}$ vii, 204 . He does not say much about the scarcity of $828 / 1426$ but tells about the repression. Cf. Ibid. viii, 77 .

41 Ibn Ḥajar, Inb $\bar{a}^{3}$ viii, 75 .

42 Ibid. 136. 
contradicted a representative of al-'Aynī about the destruction of a house. ${ }^{43}$ Once again in $842 / 1438$, they were opposed in a trial against a man who built his house against the wall of a mosque. ${ }^{44}$ In $845 / 1441$, the judicial controversy was related to the identity of the beneficiaries of a waqf. ${ }^{45} \mathrm{In}$ short, Ibn Hajar al-Asqalānī constantly questions the sentences and judicial skills of al-'Aynī. Unlike al-Maqrīzī, he did not compete with al-'Aynī for a position, as they did not belong to the same law schools. Thus, their opposition cannot be considered a consequence of such competition for an office but rather a competition for status, or maybe a classical controversy between two law schools, although these kinds of controversies seemed rare during the 15th century according to Yossef Rapoport. ${ }^{46}$

\subsubsection{Questioning the Authorial Skills}

Ibn Hajar also refers to a form of literary competition between himself and al-Aynī. This revolved more specifically around some mocking verses that he wrote against al-'Aynī, particularly on the occasion when, in 820/1417, a minaret started to bow and was about to fall on the madrasa al-Mu'ayyadiyya where al-Aynī used to teach. ${ }^{47}$ To be precise, according to Ibn Hajar, he composed his verses to make a fool of the inspector of the buildings, Ibn al-Burjī, but "a member of the council" told al-Ayni that these verses were against him. Ibn Hajar does not accept this accusation, but perhaps this was not without some hypocrisy. Although he does not tell this in his chronicle, Ibn Hajar had not hesitated in the past to mock al-'Aynī and his prosody. He does not quote al-Aynīs rhymed answer, written in the margin of the published manuscript, but claims that somebody else wrote these verses, as everybody knew he was not able to write poetry. All those verses consisted of puns about towers, eyes, and rocks. The nisba of the Hanafi judge was near the word 'ayn, which means "eye," whereas the nasab of the Shāfi'i judge was a homonym of the word hajar, which means "rock," and the name of the inspector of the buildings was built on the root burj, which means "tower." Joel Blecher says that these sorts of poetic insults, just like poetic praises, "could hold great sway in shaping one's reputation." 48

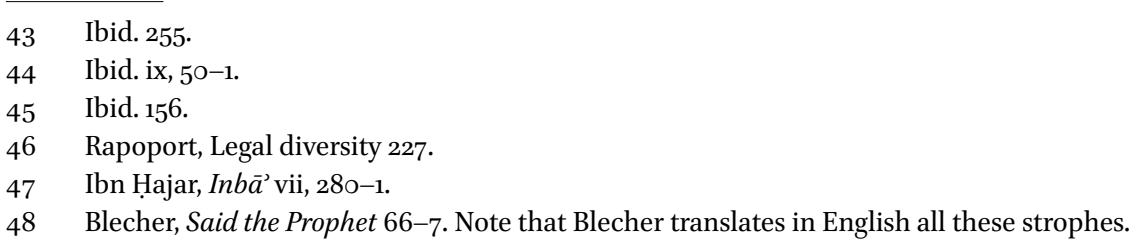


This literary controversy could have been just an anecdote if it was not related to other episodes of the relationship between both judges and if some of the following historiographers had not insisted on it.

More important than these poetic polemics was the controversy between al-'Aynī and Ibn Hajar related to their respective commentaries of al-Bukhāri’s Sahịh. Ibn Ḥajar accused al-'Aynī of having plagiarized his commentary of alBukhārī (Fath al-Bārī): One of their common students would deliver to al-'Aynī parts of the Fath al-Bärī that the latter integrated in his work ('Umdat al-Qāri') without attribution. ${ }^{49}$ Ibn Hajar even wrote an answer, entitled Intiqa $\bar{d}$ alitiräd, to denounce al-Aynì's plagiarism and criticisms. Joel Blecher deals at length with this academic feud and develops convincingly the notion of plagiarism during the 15th century. Moreover, as Blecher demonstrates, Ibn Hajar constantly revised his work during these decades in order to answer specifically to al-'Ayni's divergent interpretations of the haditth. These revisions were thus expected to enhance the different hermeneutic methods they used to practice in their commentaries. ${ }^{50}$ Considering these elements in regard to Pierre Bourdieu and Alasdair MacIntyre's thoughts, Blecher's analysis of this controversy consists of situating it at the intersection of social and intellectual history for both authors to discuss and revise their manuscripts, not only for social and material rewards but also for interpretative ends and the maintenance of standards of excellence. ${ }^{51}$ Despite the importance of this controversy in the Cairene intellectual stage, no contemporary author mentions it, not even Ibn Hajar himself. Ibn Hajar quotes al-'Ayni’s commentary among the list of his books and then just says that al-'Ayni "wrote a great part of it and then supplemented it," a sentence with a double meaning, which we can understand as al-'Aynī not having written the entire book—a hidden allusion to the plagiarism. ${ }^{52}$

Al-'Ayni’'s rivals emphasized some controversial aspects of his career in order to disqualify him as an interacting peer on the judicial and academic stage. But, by contrast with the judicial qualifications, the criticisms of the authorial qualifications are just alluded to in historiographical writings, although they are clearly questioned in the poetic and hadith literature. Obviously, intellectual interactions with academic peers used to distinguish between the domains of

49 Blecher, Said the Prophet 68, 8 o.

50 As Blecher explains, Ibn Hajar insisted on the commentary of the hadith by the hadith and the work on the chains of transmitters, while al-Aynì worked on the rhetoric rules. Blecher, Said the Prophet 80-2, 116-7.

$5^{1} \quad$ Ibid. $26,5^{6}, 71-2$.

$5^{2} \quad$ Ibn Ḥajar, Raf $^{`} 43^{2}$. 
knowledge. So, the written expressions of these discussions were distributed according to the nature of the writings. Intertextuality appears then to be a segmented process of literary communication.

\section{3}

\section{Intertextual Standards and the Evaluation of the Author}

Historiography, more than any other domain of literary communication is tied to intertextuality as the historical writings evoke or at least name and list the texts of the authors. As we have seen, the absence of mention of the books and works is meaningful as an act of disqualification and expulsion of the rarefied society of discourse. More specifically, besides the judicial qualifications, the authorial qualifications of a historian are also at stake in history writing. As the domain of the historiographic discourse is generally politics, the intertextual debate relates the author to his commitment to the military elite or his political action as a member of the court and the judicial institution.

\subsection{Questioning the Historiographical Writing}

Ibn Hajar insists on the consequences that the patronage of the amirs had for al-Ayni's historical writing. One striking example is that while he narrates the battle of al-Rastān that opposed Amir Jakam (in rebellion against Sultan Faraj) to Amir Shaykh al-Mahmūiē on Dhū l-hijja 23, 808/June 11, 1406, he says that al-Aynī exaggerates in favor of Jakam in his chronicle and quotes a few sentences from the Iqd al-jumān that end with the assessment that Jakam had fewer soldiers than Shaykh and that God gives the victory to whom he wants. The conclusion that gives the divine protection to Jakam is obviously the words that Ibn Hajar questions. $.^{53} \mathrm{Al}-\mathrm{A}$ Aynī himself does not hesitate to write that he was under the protection of this amir. Although Donald Little considers him as more temperate than al-Maqrīzì in his study of year $824 / 1421,{ }^{54}$ we must recognize that he is sometimes a sort of activist in favor of Jakam's memory. According to him, no amir could be compared to him, relating to his courage and boldness. ${ }^{55}$

Metatextuality in historiography is used here as a procedure of the disqualification of the historian. The value of his writings is questioned in relation to his political commitment since the author does not show enough neutrality. Impartiality—or rather, the appearance of impartiality—can then be ranked

53 Ibn Ḥajar, Inb $\bar{a}^{\mathrm{N}} \mathrm{v}, 3 \mathrm{O2}$.

54 Little, Comparison 215.

55 Al-'Aynī, 'Tqd, ed. Bīnū, 186-7. 
among the standards of excellence in history writing. Transposing Blecher's analysis into historiography, it could be said that the discussion between the authors is not only related to the competitive social field they belong to but also to the maintenance of such standards; that is, at the intersection of social and intellectual history.

\subsection{Intertextual Recurrent Themes}

3.2.1 Recurrent Themes on al-Maqrīzī and Ibn Ḥajar in al-'Aynì's Chronicle

Al-Aynī himself used these sorts of procedures of disqualification against his colleagues. It is noteworthy that he could forget to mention in his chronicle Iqd al-jumān fì ta'rīkh ahl al-zamān some important former historians, like Ibn al-Furāt (d. 801/1399), on whom he did not write an obituary, whereas he did not hesitate to present his contemporary rivals with negative connotations. The evocation of the historians then appears to be linked to the competitive relationship he had with them. ${ }^{56}$ For example, although al-Maqrīzī is almost never mentioned in the Iqd al-jumān, al-'Ayni only speaks about his appointments and dismissals as a muhtasib; that is, the events related to his rivalry with al'Aynī. ${ }^{57} \mathrm{He}$ is indeed the only one who gives a negative narrative of al-Maqrīzì's behavior when al-'Aynī, after having been appointed instead of al-Maqrīzī, was replaced by him in 801/1399. Al-'Aynī, as he himself says, was dismissed from the hisba because he refused to collaborate with Amīr Sayyidī Sūdūn's impious practices of speculation during a food shortage. Nobody accepted to replace him except al-Maqrīzī, whose honesty is then implicitly questioned. ${ }^{58}$ The last mention of al-Maqrīzī that I was able to find in al-'Aynī's chronicle is his dismissal four months later, caused by another act of bribery when one of al-Ayni's and al-Maqrīzìs competitors for the hisba bribed another amir to obtain this appointment, ${ }^{59}$ which indicates that this practice was common. ${ }^{60}$ The obituary of al-Maqrīzì is also particularly mocking. Al-Maqrīzī, he says, "used to write chronicles and to practice geomancy." The shortness of the text in itself looks like criticism as, besides this remark, he only mentions twice that he was appointed as a muhtasib. Once again, he is the only historian who adds that this

$5^{6}$ As the chronicle ends in 850/1446, before the death of Ibn Ḥajar al-'Asqalānī (d. 852/1448), al-'Aynī never wrote a biography of his preferred rival.

57 Al-'Aynī, Iqd, ed. Shukrī, 485. Al-'Aynī, Tqd, ed. Bīnū, 75, 142, 203.

$5^{8}$ Al-'Aynī, Iqd, ed. Bīnū, 186-7.

59 Ibid. 203.

6o Martel-Thoumian, Sale 50-83. 
appointment was due to the intercession of Amīr Sayyidī Sūdūn, ${ }^{61}$ so we may suggest that this statement is an answer to the chroniclers who explain how al-'Aynī benefited from Amīr Jakam's intercessions. ${ }^{62}$ Obviously, al-'Ayni’s biography of al-Maqrīzī is a specific answer to al-Maqrīzì's biography of al-'Aynī. The shortness of both texts and the abbreviation of the biography to the early career of each author aim to denigrate the crucial role they both had in the Cairene academic stage. ${ }^{63}$

Regarding Ibn Ḥajar al-'Asqalānī, al-'Aynī mentions mainly his successive positions. ${ }^{64}$ It is noteworthy that he suspects Ibn Hajar to be the author of some verses that made a fool of some other 'ulama $\bar{a}$ during a quarrel. ${ }^{65}$ We may suggest that this suspicion was caused by the minaret quarrel with al-'Aynī, where Ibn Hajar claimed not to be the author of mocking verses against al-'Aynī, as we have seen before. So, it seems that anonymous verses were a usual way of Ibn Ḥajar's academic action. ${ }^{66}$ Moreover, al-Aynī mentions several times Ibn Hajar's rivalry with the Shâfi'i great judge al-Harawwī, who he obviously supports. ${ }^{67}$ But, as far as I know, he never mentions his controversy with Ibn Ḥajar, neither about the plagiarism nor about the minaret affair. He quotes the verses that were written against al-Burjī, who was responsible for the construction, but he does not mention the verses Ibn Hajar wrote against him or his rhymed answer. ${ }^{68}$

Nevertheless, al-'Aynī mentions once their controversy, but he considers it a disgraceful and false accusation of al-Ayni's enemies, probably his rival to the office of Hanafi great judge, al-Tifihnī. ${ }^{69}$ It is true that Ibn Hajar was never in competition with al-Aynī for an office, unlike al-Tifihnī. Whoever was the accuser, he obtained al-'Ayni’s and Ibn Hajar's dismissals simultaneously in $833 / 1429$ with the statement that they never cease to quarrel and neglect the

\footnotetext{
61 He is named Sūdūn b. ukht al-Ẓāhir in this text.

62 Al-'Aynī, Iqd, ed. al-Qarmūț ii, 574.

63 As he was working on the year 824/1421, Donald Little mentions that it has been suggested that al-'Aynī did answer to al-Maqrīzī without naming him in his chronicle. Little, Comparison 210.

64 Al-'Aynī, 'Tqd, ed. Qarmūț i, 142-3; ii, 227, 251, 372, 403.

65 Ibid. i, 321.

66 Verses were a highly regarded act of communication among the 'ulamä. For example, al'Aynī quotes a legal question in verses that had been asked to him and his rhymed fatwā. Al-'Aynī, Iqd, ed. Qarmūț, ii, 647. Thomas Bauer proposes a similar idea, insisting on the role of "occasionality" in Mamluk literature writing. See Bauer, Mamluk literature as a means of communication $23-56$.

67 Al-'Aynī, Iqd, ed. Qarmūț i, 352-3; ii, 251.

68 Ibid. i, 306.

69 The very negative obituary of al-Tifihnī is explicit on their hostility. Ibid. ii, 422 .
} 
common good of the Muslims. ${ }^{70}$ The anecdote makes it clear, however, that our author did not lose the sultan's confidence after this event, and eventually, he was reappointed as muhtasib two months later ${ }^{71}$ and replaced al-Tifihnī as great judge two years later. ${ }^{72}$ The controversy is then deliberately obliterated in the Iqd al-jumān.

Once again, the poetic and hadīth polemics are not at stake in the contemporary historiographical writings. By contrast, the mention of the intrigues and the commitment to the military elite are recurrent themes in the texts that mention the social life of al-'Aynī, so that he had to justify himself and counterattack on the very same topics.

\subsubsection{Al-'Ayni's Justification}

Indeed, his annals include several pages of justifications. Beyond the mentions of his fellow historians, al-'Ayni's chronicle gives the subjective point of view of the author about the events of his life that his colleagues evoke. He is the first one who writes about his expulsion from the madrasa al-Ẓāhiriyya ${ }^{73}$ and who mentions Amī Jakam's patronage. ${ }^{74}$ In regards to the exercise of the hisba, he justifies himself at length about his role during the scarcity of 818-9/14156 but does not speak much about the scarcities of 828 and $829\left(1425^{-6}\right)$ during which he was also the muhtasib. ${ }^{75}$ In contrast with the works of his colleagues, his intimacy with the sultans is described as positive behavior. In several pages of his chronicle, al-Aynī insists on his friendship with the sultans Shaykh ${ }^{76}$ and Țațar, ${ }^{77}$ to whom he wrote panegyrics, ${ }^{78}$ and Barsbāy. ${ }^{79} \mathrm{He}$ also likes to say when he was a witness or a participant in an important event at the court of Sultan Barsbāy. ${ }^{80}$ In one of these occurrences, his chronicle mise en abyme, the author mentions the book in the book when he says that he was reading it to Sultan

$70 \quad$ Ibid. ii, 372.

71 Ibid. ii, 373 .

72 Ibid. ii, 418.

73 Al-'Aynī, Iqd, ed. Shukrī, 192-3.

74 Al-'Aynī, Iqd, ed. Bīnū, 186-7, 203.

75 Al-'Aynī, 'Iqd, ed. Qarmūṭ i, 241-4.

76 Ibid. i, 256-7.

77 Ibid. i, 256; ii, 155 .

78 The rhymed panegyric to Sultan al-Mu'ayyad Shaykh is entitled Al-Jawhara al-sinniyya fi Ta'rikh al-dawla al-Mu'ayyadiyya. The nonrhymed version is entitled Al-Sayf al-muhannad fi sìrat al-malik al-Mu'ayyad. The panegyric to Sultan al-Zāhir Ṭațar is entitled Al-Rawḍlzāhir fis sìrat al-malik al-Z̄ähir.

79 Al-'Aynī, 'Iqd, ed. Qarmūții, 227.

8 o Ibid. ii, 313, 319, 320-1, 407. 
Barsbāy. ${ }^{81}$ By contrast, he does not say a word about his difficult relationship with Sultan Jaqmaq. The last one of his panegyrics dedicated to him ${ }^{82}$ failed to reach his goal as Jaqmaq dismissed him progressively from all his offices. The dismissal from the office of Hanafi great judge in $842 / 1438$ is another occasion to justify himself, as it is said to have been ordered "without any cause." 83

It is striking that our three authors chose the same facts and the same topics to assess the value of al-'Ayni’s life in their historical writings: his position vis-àvis the military elite, his judicial competences and practice as a judicial officer and a historian, but considered that his competences as a poet and exegete were a minor, or at least a nonhistorical, matter.

Whereas al-Maqrīzī and Ibn Ḥajar's historiographical writings define a subjective portrait of al-'Aynī, integrating the object's subjective point of view on his colleagues in such a complex dialogue that is allows us to draw more than portraits - an arena. Al-'Aynîs way to handle his colleagues is helpful in this project, as he speaks explicitly about them and actually stages this conflictual academic arena. His position is defined by the very same criteria his rivals used, but symmetrically. Al-Maqrīzī is accused of being an intrigant, and al-'Aynī's relationship with the military elite is considered a positive one. In short, in al-Ayni's writings appears a symmetrical position that gives a second dimension to the portraits that can be found in his rivals' literature. The perspective I would like to suggest in this article is then somewhat different than Anne Broadbridge's description of the rivalry between those three historians. ${ }^{84} \mathrm{My}$ objective is not to define the social position of the author in the academic field but to show how this position finds its expression through a literary position. In other words, how is al-Aynī a persona in the polyphonic stage of historical writing? ${ }^{85}$ In this stage, the fact that the authors chose to mention their rivals rather than other historians is a clue that this sort of writing can be apprehended as an act of competitive communication inside the academic field. This creates a dialogue where the authors conceive their works as an answer to the works of their colleague. ${ }^{86}$ The recurrent themes and even events that are dis-

81 Al-'Aynī, 'Iqd, ed. Qarmūt ii, 487.

82 The panegyric to Sultan Jaqmaq is wrongly considered as a panegyric to Sultan Baybars entitled Ta'rīkh al-Malik al-Zūhir Mahmūud Shäh Baybars; BnF mss. Arabe 5818. It can be found in the Bibliothèque Nationale.

83 Al-'Aynī, Iqd, ed. Qarmūț ii, 510.

84 See Broadbridge, Rivalry.

85 On the plurality of historiographical voices in the 15th-century Cairene academic scene, see Van Steenbergen and Van Nieuwenhuyse, Truth 147-87.

86 On this topic, the analysis of the chronicles can be compared to Blecher's analysis of the revisions of the haditth commentaries. 
cussed are then engaged in normative intertextuality since the recurrence of these topics in echoing texts defines the standards of the social position of the historians related to his historiographical writings: fair in his judicial activity and impartial in his relationships with the military elite.

\section{The Author's Persona as a Process}

A question must then be asked: What dialogue do we have? Who answers to whom? The first piece of information about al-'Aynī comes from his own work. The volume of the Iqd al-jumān related to the reign of Sultan Barqūq is plausibly the oldest of all these historiographical writings. But these books were not written in one day. For example, the first time al-'Aynī is mentioned in Ibn Ḥajar's Inbä' al-ghumr, he is not named al-'Aynī or al-'Ayntābī but "al-Shaykh Badr al-Dīn Maḥmūd b. Aḥmad al-Ḥanafi." ${ }^{87}$ In all the historiographical writings, it is the only time his geographical origins are forgotten in his name. ${ }^{88}$ This is probably a clue that Ibn Hajar wrote this page early in his career and certainly before al-Ayni's onomastic title was stabilized. ${ }^{89}$ This is just one example that shows that this historiographical writing worked as a complex dialogue where it is not always possible for the modern historian to say which author wrote first about an event or an individual. For example, Donald Little, as well as Sami Massoud, both note that when each one of them compares al-Maqrīzī and al'Ayni’s chronicles, they were not able to clarify who copied the other. ${ }^{90}$

\subsection{Different Temporalities in Biography Writing}

The various biographies belong to different temporalities, which may explain why they do not deal with al-'Aynì as a regular member of the 'ulam $\bar{a}$. They have been written while their object was still alive. The Durar biography, as well as the $I n b \bar{a}^{\prime}$ biography, may have been written when both al-Maqrìzì and al-'Aynī had fallen into disgrace, at the end of Sultan Faraj's reign, ${ }^{91}$ so they do not hesitate to be negative. Ibn Hajar's biography in the Raf' al-iṣr was written later, when al-Aynī was one of the most prominent dignitaries of the state,

\footnotetext{
87 Ibn Hajar, Inbā' iv, 33-4.

88 The author calls himself musattiru-hu - "its composer"-but sometimes he writes his own name, always with his geographical nisba "Maḥmūd al-Ayn̄̄" or "Mạ̣mūd al-'Aynī al-Hanafī," al-'Aynī Iqd, ed. Qarmūṭ ii, 479, 498.

89 Perhaps he copied later some earlier notes.

90 Little, Comparison 210; Massoud, Chronicles 159-6o.

91 No biography mentions his comeback under Sultan al-Mu’ayyad Shaykh.
} 
even after his dismissal as a great judge. So, he criticizes him with some caution. Symmetrically, al-'Aynī criticizes al-Maqrīzì in his obituary, at a time he could not answer anymore. The temporality of writing is an essential aspect of historiography, as the career of the authors may evolve in various ways. In contrast with the biographies, the chronicles are written progressively, so the writing does not present a state of the life and career but several appearances that can show a dynamic representation of the academic field. ${ }^{92}$

\subsection{Ibn Hajar's Changing Relationship with al-'Aynī}

Accordingly, Ibn Hajar's In $b \vec{a}$ ' seems to have evolved with the renewal of the interactions between the two great judges. In Ramadān 836/April 1433, during Sultan Barsbāy's expedition to Āmid and the Northern provinces, al-'Aynī invited Ibn Hajar to his homeland in 'Ayntāb (now Gaziantep, Turkey). What is interesting is that he did not invite the other judges or dignitaries who accompanied the sultan. These two old colleagues must have had a sort of mutual respect. Despite their longstanding rivalry, they interacted as equals and as what the sources would usually call suhba (friendship). ${ }^{93}$ From the 840 on (after 1437), Ibn Hajar makes positive notes about al-Aynī. For example, the narrative of al-'Ayni’s dismissal by Sultan Jaqmaq in Muharram 842/July $1438^{94}$ is quite different from al-Maqrizì's narrative, ${ }^{95}$ as he explains that the amirs and secretaries did not walk in his successor's procession-as the custom demands-but went to al-'Aynī's home. Al-Maqrīzī notes al-'Aynī's popularity among the amirs at this occasion, too, but from the successor's negative point of view; the new judge demanded that no amir may appeal to him. Later, Ibn Ḥajar notes al-Ayni's popularity among the population as well, as he mentions the joy of the people when he was reappointed as a muhtasib in Rabī' I 844/August 1440. ${ }^{96}$ Symmetrically, in al-Aynīs work, as he himself endured a redemption under Ibn Hajar's pen, his controversy with the Shāfi'i great judge is entirely obliterated.

92 Regarding the dynamic nature of chronicle writing, we may compare al-'Aynï's writing to Frederic Bauden's statement about al-Maqrīzī who continued writing the Sulük between 820/1417 and 844/1442. See Bauden, Taqī 181.

93 Al-'Aynī does not speak much of this reconciliation and eventually the all travel to 'Ayntāb is quite shortly depicted, although this must have been an important time in his personal life as he intended, he says, to meet again his remaining brothers and friends. Al-Aynī, Iqd, ed. Qarmūṭ ii, 430-2.

94 Ibn Ḥajar, Inb $\bar{a}^{3}$ ix, 31.

95 Al-Maqrīzì, Sulūk iv, 1069.

96 Ibn Ḥajar, Inb $\vec{a}$ ix, 126. 
This evolution in Ibn Hajar's writing is a witness of how important it is to apprehend the dyadic interactions in their diachrony. The redaction of a chronicle used to last a long time, generally decades, and this time-lapse has obvious repercussions for the writing of history. This marks an important contrast with the biographical dictionaries when it refers to the relationships with a biographed person.

Al-Maqrīzī and Ibn Ḥajar define in their historiographical writings their position vis-à-vis al-'Aynī. Besides some "objective facts," such as the institutional offices he held successively, both their positions emphasize some common informative choices: the relationship with the military elite, the intrigues, the lack of competences that are shaded by their personal agendas and interest in the hisba or the judiciary. Interestingly, the question of the relationship with the military elite and the practice of the intrigues in order to obtain important positions create, in their writings, a discursive incompatibility between a central position in the military and academic fields. But this discursive position in the social field changes according to the evolution of the relationships between the authors and the offices they held: even al-Maqrīzī, finally, added a list of al'Ayni's works in a biography where the latter was, in his vision, a pariah of the academic field.

In short, under al-Maqrīzì's and Ibn Ḥajar's pen, al-'Aynī appears as an unusual scholar, a controversial and scandalous man, and a self-interested intriguer who compromised with the military power and, thanks to this commitment, manages to access undeserved positions, but who is also, finally, recognized as a leading scholar by his peers and a dignitary of the state in formation.

\subsection{Memory Writing and the Crystallization of the Literary Persona}

The evolution of the representation of our author did not stop with his death. Al-'Aynì (762-855/1361-1451) died when he was 93 lunar years old, in 855/1451, after having been a major dignitary of the realm for more than 30 years. What representation of him is left after his death? What memory of him did his epigones write? In contrast with the ones mentioned above by his contemporaries, the later biographies are longer and follow the structure of the classical tarjama of the 'ulam $\bar{a}$.

Al-'Aynī's biography in Ibn Taghrī Birdì's (813-74/1411-70) Manhal is almost a panegyric. ${ }^{97}$ The author was one of his students and got a complete license (ijāza) for all of al-Aynīs works. He expressed a true devotion to his master, 
and he is the only historian who gives a positive version of all the controversial events of al-Ayni's life. His work inherits the intertextual themes and facts that had been emphasized by the former historians. He contradicts Ibn Hajar implicitly when he explains that he exercised judicial authority with competence and honor and when he claims that he did not become judge thanks to an intrigue. As al-'Aynī himself, he considers with respect and admiration his intimacy to the sultans. The biography ends with an impressive list of the sciences at which he excelled ( figh, ușül, languages, grammar, conjugation, history, hadith) and an organized list of his books (commentaries, summaries, histories). The peculiarity of this biography is that the list of his sciences and works is presented twice: the first time when he deals with his role under Sultan al-Mu'ayyad Shaykh and the second time at the very end of the biography. There are two possible explanations for this: Either Ibn Taghrī Birdī wanted to insist on his scholarly activity during Sultan Shaykh's reign, or he wrote the first biography in his early life ${ }^{98}$ which he completed later, after al-Aynīs death in $855 / 1451 .{ }^{99}$

Al-Sakhāwī (831-902/1428-97) wrote three biographies of al-'Aynī that are all copies of the same text with minor differences, the main difference being the length. ${ }^{100} \mathrm{Al}$-Sakhāwì's biography is the most complete one, and it is a model of

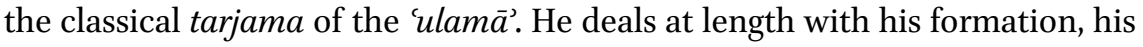
works, and knowledge. As Ibn Taghrī Birdī, he is reliant on the pieces of information he held from his masters, and thus he refers to the recurrent themes and topics identified earlier. As he was a disciple of Ibn Hajar, he shows him as an intriguer and contradicts Ibn Taghrī Birdī when he explains the plots he made in order to become a Hanafi great judge. Despite this reliance on former biographies, al-Sakhāwīs biographies give a lot of original pieces of information that the contemporary authors neglected to mention. Examples are the fact that Ibn Hajar's son got a license from al-Aynī-a piece of information that confirms the impression that their relationship evolved a lot during their lifetime - and that he is the first person to present a detailed narration of the plagiarism affair. Nevertheless, al-Sakhāwì's texts are generally laudatory. This can be explained by the fact that he was also one of al-Ayni's students and that he deserved his congratulations. At the end of his version of the biography in

98 Certainly not under Sultan Shaykh's reign because he was ten years old at the end of the reign, but perhaps when he was al-'Aynī's student.

99 Al-Aynī's obituary in the Hawādīth al-duhūr is a very short summary of his Manhal's biographical note that insists on his close relationship with Sultan Barsbāy. Ibn Taghrī Birdī, Hawādìth ii, 354 .

100 Al-Sakhāwī, Dhayl 428-40; al-Sakhāwī, al-Tibr iii, 14O-8; al-Sakhāwī, al-Paw’ x, 131-5. 
the Dhayl Raf' al-ișr, he adds two panegyric verses that evoke both his good exercise of the hisba and the panegyric he wrote for the sultan. ${ }^{101}$

Al-Suyūṭi (849-911/1445-1505) wrote three very different biographies of al'Aynī. ${ }^{102}$ The obituary of the Husn al-muhâdara is obviously a summary of the biography written in the Nazm al-iqyān. The latter is a (short) model of a tarjama of the 'ulamā' as described earlier. But the tarjama of the Kitāb Bughyat al-wu'a $\bar{h}$ is different. ${ }^{103}$ The book is a biographical dictionary of the grammarians and the linguists, so the biography emphasizes this aspect of al-'Ayni's work. Although the tone is generally positive, al-Suyūṭi severely criticizes his poetry and evokes Ibn Hajar's mockery about his verses in Sultan Shaykh's rhymed panegyric. He is the one who quotes Ibn Ḥajar's verses against al-'Aynī about the bowing minaret, but not al-'Aynī's answer.

Al-'Aynī's obituary by Ibn Iyās $\left(85^{2-930 / 1448-1523}\right)^{104}$ is a short but exclusively positive text. He insists on his qualities as a historian by saying that his transmission of history was authentic and truthful. Interestingly, he mentions his skills in poetry as well, although there is little doubt that he knew the controversy about this question with Ibn Hajar. The conclusion consists of two laudatory verses composed by an anonymous poet.

Al-'Aynī's discursive representation is far more positive under his successors' pen, with the exception of one of al-Suyūțī's biographies. During the decades that followed al-Ayni's death, a memory was built that was not involved in the scholars' controversies but was dependent on the texts that staged these controversies and on the personal relationships the new authors had with their object. Both Ibn Taghrī Birdī and al-Sakhāwī- the two first generations-were students of al-Ayni. The first one is laudatory and entirely dependent on his point of view. The second one is a student of both al-'Aynī and Ibn Ḥajar, and he elaborates a consensual position that could not be possible before the reconciliation of his masters. Although they belong to the same generation, al-Suyūțī and Ibn Iyās present very different texts. Ibn Iyās seems to mostly rely on Ibn Taghrī Birdì's portrait, and it looks like a summary of it. But al-Suyūṭ̄ is puzzling. His classical biographical note in two of his works seems to follow the academic consensus that had been elaborated at al-Sakhāwīs time, and he recognizes the scholar of great renown that al-'Aynī was. But he adopts entirely Ibn Hajar's controversial position in the other biographical note. Thus, he writes two totally different biographies of al-'Aynī, according to the topic of each one of these bio-

\footnotetext{
101 Probably Sultan al-Mu’ayyad Shaykh.

102 Al-Suyūṭī, Nazm 174-5; Husn 473-4; Bughyat 386.

103 Al-Suyūṭī, Bughyat 386.

104 Ibn Iyās, Badā'ic 292-3.
} 
graphical books. The common and main evolution of all these late biographies is its tarjama al-'ulamä' structure: al-'Aynī had become an eminent scholar after his death. He is then mentioned not just as an intimate of the military elite or as a powerful intrigant but as a great exegete and even as a poet. His elite academic status was finally recognized and published by his epigones. As they could not conceal the various controversies that he was submitted to during his lifetime, they made him a figure of the academic fitna.

\section{$5 \quad$ Conclusion}

The literarization of the author's persona is a complex social interaction where the organization of the academic field is at stake, not only through a performative biographical definition of its membership but also through the expression of the standards of evaluation of its member. Indeed, thanks to various discursive procedures, the historians exclude or integrate a scholar among the academic elite, and they emphasize some aspects of his life and career in order to evaluate his status inside the group. This evaluation is performative in that it may influence his reputation and then his career.

The place of the historians in this competition is emphasized because history writing, like poetry, is a specific means of communication inside this milieu that stages the social group, its members, and its quarrels. It creates a peculiar dialogue, which leads some of them to wish to take part in this dialogue in order to defend their social existence and their distinctive situation in their milieu by expressing it.

The 15th century experienced the success of this dialogue and historical controversy as a plurality of voices raised. Various representations of the objectivated author were then depicted according to the different agendas of the historians. In the case of al-'Aynī, this polyphony converged toward an intertextual dialogue where the social and authorial practices and qualifications were discussed in relation with selected themes and facts. What emerges from this polyphony is not only a common persona but also the definition of the social and literary standards of evaluation of the field. To be precise, only some of the standards of evaluation appear in the contemporary historiographical writings. Obviously, not everything is an object of history. The discussions in exegesis and poetry are known only thanks to exegetic and poetic writings or thanks to later historiographical writings. Like exegesis or poetry, historiography is just one of the competitive domains of knowledge, but it is also the intertextual place where the social activity of the authors is discussed by itself. In other words, historiography is not a social field in se. The social field where the competition 
takes place is the 'ulama' milieu, in which historiography is a peculiar domain of knowledge as it stages the social activity of the scholars.

As history writing is a lifetime activity among the 15th-century Cairene scholars, it appears to be a dynamic social interactive behavior. The literarized persona evolves according to the evolution of his career and social interactions with the other historians. In other words, the evolution of the discourse is related to the evolution of the position of the individual in the academic and military fields. This process continues after his death and becomes an act of moral sedimentation of the individual as an exemplum through the polyphonic crystallization of a common memory.

Al-'Aynī appears to be a key author to understand these phenomena, not only because he stood at the core of multiple rivalries, networks, and social fields, but also because his social position and career evolved a lot during his life. His constant conflictual relationships with al-Maqrīzī led to a point-bypoint controversy where, after having been denigrated as a member of the scholarly milieu, he tried to reverse either the accusations or the values that were understood to be the standards of evaluation in the academic field. Notably, al-Aynī argued in favor of the intimacy to the military power. Such a divergence of opinion shows their asymmetrical institutional situations. By contrast, the relationships with Ibn Hajar evolved toward a peer-to-peer controversy as the asymmetrical religious and judicial position was counterbalanced by al'Ayni's institutional superiority in historiography. ${ }^{105}$ In the end, this situation led to a reconciliation on the basis of their common highly recognized status. The historiographical traces of both controversies and reconciliations were the literary basis for the diachronic construction of the ambiguous persona of a great scholar and a controversial courtier in the memory of the Cairo Sultanate, and finally a figure of the academic rivalries.

105 Blecher remarks this asymmetry as the Shāfici judge was hierarchically superior to the Hanafì judge and had the privilege to comment the Saḥ̆h in front of the sultan, but he doesn't note that, on the contrary, it was al-'Aynī who had the privilege to read his chronicle to the sovereign. See Blecher, Said the Prophet 64. 


\section{Bibliography}

\section{Primary Sources}

al-Aynī, al-Raw ḍ al-Zāhir fì sīrat al-malik al-Zāhhir (Ṭaṭar), ed. H. Ernst and I. El Baby El Halaby, Cairo 1962.

al-'Aynī, 'Iqd al-jumān fì tārīkh ahl al-zamān, ed. 'A. al-Ṭanțāwī al-Qarmūṭ, 2 vols., Cairo, $1985-9$.

al-'Aynī, al-Sayf al-muhannad fı̀ sīrat al-Malik al-Mu'ayyad, ed. F.M. 'Ulwī Shaltūt and M.M. Ziyāda, Cairo 1998.

al-'Aynī, al-Sulțān Barqūq mu'assis dawlat al-mamālīk al-jarākisa min khilāl makhțūt

'Iqd al-jumān fì tārīkh ahl al-zamān li-Badr al-'Aynī, ed. İ.'U. Shukrī, Cairo 2002.

al-'Aynī, Iqd al-jumān fì tārīkh ahl al-zamān, ed. I.Y. Bīnū, Amman 2011.

al-Aynī, Iqd al-jumānfìtārīkh ahl al-zamān, Mss Istanbul Sultan-Ahmet Library A 291119.

al-'Aynī, Ta’rīkh mudda wilāyat al-Malik al-Ẓāhir Maḥmūd Shāh Baybars, BnF mss. Arabe 5818.

Ibn Ḥajar al-'Asqalānī, Inbāà al-ghumr bi-abnā’ al-'umr, ed. A.A. Khān, 9 vols., Hyderabad $1969-76$.

Ibn Ḥajar al-'Asqalānī, Raf' al-iṣr 'an quḍāt Miṣr, ed. 'A.M. 'Umar, Cairo 1998.

Ibn Iyās, Badā'i al-zuhūr fì waqā̄i al-duhūr, ed. M. Mușțafā, 2 vols., Wiesbaden 1972.

Ibn Taghrī Birdī, al-Manhal al-ṣăfı́wa al-mustawfā ba'd al-wāfā, ed. M.M. Amīn, 13 vols., Cairo 1984-2005.

Ibn Taghrī Birdī, Hawādīth al-duhūrfìmadā al-ayyām wa al-shuhūr, ed. M.K. 'Izz al-Dīn,

Beirut 1990.

al-Maqrīzī, Kitāb al-Sulūk li-ma'rifa duwal al-mulūk, ed. M.M. Ziyāda and S.'A. 'Āshūr, 4 vols., Cairo 1956-73.

al-Maqrīzī, Kitāb al-Muqaffā al-kabìr, ed. M. al-Ya'lāwā, Beirut 1991.

al-Maqrīzì, Durar al-'uqūd al-farìda fì tarājim al-a yān al-mufìda, ed. M. al-Jalili, 4 vols.,

Beirut 2002.

al-Sakhāwī, al-Daw' al-lāmi' li-ahl al-qarn al-tāsi', unmentioned editor, Beirut 1992.

al-Sakhāwī, Kitāb al-Tibr al-masbūk fì dhayl al-sulūk, ed. S.'A. 'Āshūr, N.M. Kāmil and

L.I. Mușțafā, Cairo, 4 vols. 2002-7.

al-Sakhāwī, al-Dhayl 'alā raf' al-iṣr aw bughyat al-'ulamā' wa-l-ruwāt, ed. J. Hilāl and

M.M. Șubh, Cairo n.d.

al-Suyūțī, Kitāb Bughyat al-wu'āh fì țabaqāt al-lughawiyyīn wa al-nuḥhāh, ed. M.A. al-

Khānjī and A.N. al-Jamālī, Cairo 1908.

al-Suyūṭī, Nażm al-'iqyān fì a'yān al-áyān, ed. P.K. Hitti, New York 1927.

al-Suyūṭī, Ḥusn al-muhạậara fì ta'rīkh Miṣr wa al-Qāhira, ed. M.A. Ibrāhīm, Cairo 1967. 


\section{Secondary Sources}

Bauden, F., Taqī al-Dīn Aḥmad ibn 'Alī al-Maqrīzī, in A. Mallett (ed.), Medieval Muslim historians and the Franks in the Levant, Leiden and Boston 2014.

Bauer, T., Mamluk literature as a means of communication, in S. Conermann (ed.), Ubi Sumus? Quo Vademus? Mamluk Studies - State of the art, Göttingen 2013, 23-56.

Blecher, J., Said the Prophet, hadith commentary across a millennium, Oakland 2018.

Bourdieu, P., Raisons pratiques, Sur la théorie de l'action, Paris 1994.

Broadbridge, A.F., Academic rivalry and the patronage system in fifteenth-century Egypt: Al-'Aynī, al-Maqrīzī, and Ibn Ḥajar al-'Asqalānī, in MSR 3 (1999), 85-107.

Chamberlain, M., Knowledge and social practice in medieval Damascus: 1190-1350, Cambridge 1994 .

Conermann, S., Tankiz ibn 'Abd Allāh al-Ḥusāmī al-Nāṣirī (d. 740/1340) as seen by his contemporary al-Ṣafadī (d. 764/1363), in $M S R$ 12/2 (2008), 1-24.

Eickelman, D., Tardjama, in $E I^{2}, \mathrm{x}, 242-3$.

Foucault, M., L'ordre du discours, Paris 1971.

Gharaibeh, M., Brokerage and interpersonal relationships in scholarly networks. Ibn Ḥağar al-'Asqalānī and his early academic career, in S. Conermann (ed.), Everything is on the move: The Mamluk empire as a node in (trans-)regional networks, Bonn 2014, 223-66.

Guérin du Grandlaunay, R., Iršād al-j̄āwì bal is ād al-țālib wa-l-rāwì li-l-ilāam bi-tarğamat al-Sahāwì̄. Édition et analyse de la première partie de l'autobiographie d'al-Sahāwì̄ (831-902/1428-1497), PhD diss., Paris 2015.

Haarmann, U., Quellenstudien zur frühen Mamlukenzeit, Freiburg 1969.

Al-Hajeri, S.A., A critical edition of the eleventh volume of the Iqd al-jumān fì tārīkh ahl al-zamān, PhD diss., Edinburgh 2007.

Hirschler, K., Medieval Arabic historiography, authors as actors, London 2006.

Little, D.P., History and historiography of the Mamlüks, London 1986.

Little, D.P., A comparison of al-Maqrīzī and al-'Aynī as historians of contemporary events, $M S R$ 7/2 (2003), 205-15.

Martel-Thoumian, B., The sale of office and its consequences during the rule of the last Circassians (872-922/1468-1516), in MSR 9/2 (2005), 50-83.

Massoud, S.G., The chronicles and annalistic sources of the early Mamluk Circassian period, Leiden 2007.

Ma'tūq, S.Y., Badr al-Dìn al-'Aynì wa ataruhu fì 'ilm al-hadīth, Beirut 1987.

Nakamachi, N., Al-'Aynì's chronicles as a source for the Bahrī Mamlūk period, in Report of the society for Near Eastern studies in Japan 40 (2005), 140-71.

Rapoport, Y., Legal Diversity and the Age of Taqlīd: The Four Chief Qāḍīs under the Mamluks, Islamic Law and Society 10/2 (2003), 210-228.

Saleh, M.J., Al-Suyūṭī and his works: Their place in Islamic scholarship from Mamluk times to the present, in MSR 5 (2001), 73-89. 
Tillier, M., Vie des Cadis de Mișr, Cairo 2002.

Van Steenbergen, J., The amir Yalbughā al-Khāṣṣakī, the Qalāwūnid Sultanate, and the cultural matrix of Mamlūk society: A reassessment of Mamlūk politics in the 136os, in JAOS 131/3 (2011), 423-43.

Van Steenbergen, J., and S. Van Nieuwenhuyse, Truth and politics in late medieval Arabic historiography: The formation of Sultan Barsbāy's state (1422-1438) and the narratives of the amir Qurqumās al-Sha'bānī (d. 1438), in Der Islam 95/1 (2018), 14787.

White, H., Tropic of discourse: Essays in cultural criticism, Baltimore 1978. 